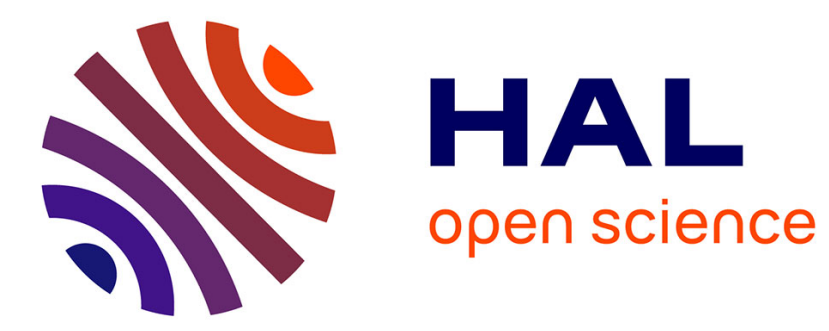

\title{
The diet of osprey Pandion haliaetus on Marawah Island (Abu Dhabi Emirate, United Arab Emirates) and its implications for the study of archaeological assemblages
}

Kevin Lidour, Mark Jonathan Beech

\section{- To cite this version:}

Kevin Lidour, Mark Jonathan Beech. The diet of osprey Pandion haliaetus on Marawah Island (Abu Dhabi Emirate, United Arab Emirates) and its implications for the study of archaeological assemblages. Journal of Archaeological Science: Reports, 2020, 33, pp.102532. 10.1016/j.jasrep.2020.102532 . hal-03418252

\section{HAL Id: hal-03418252 https://hal.science/hal-03418252}

Submitted on 6 Nov 2021

HAL is a multi-disciplinary open access archive for the deposit and dissemination of scientific research documents, whether they are published or not. The documents may come from teaching and research institutions in France or abroad, or from public or private research centers.
L'archive ouverte pluridisciplinaire HAL, est destinée au dépôt et à la diffusion de documents scientifiques de niveau recherche, publiés ou non, émanant des établissements d'enseignement et de recherche français ou étrangers, des laboratoires publics ou privés. 
Journal of Archaeological Science: Report $30 \quad$ (2020): 102532 https://doi.org/10.1016/i.jasrep.2020.102532

The diet of Osprey Pandion haliaetus on Marawah Island (Abu Dhabi Emirate, United Arab Emirates) and its implications for the study of archaeological assemblages.

\section{Kevin Lidour ${ }^{1}$, Mark Jonathan Beech ${ }^{2}$}

1. UMR 7209 (AASPE), Muséum National d'Histoire Naturelle, CP 56, 55 rue Buffon, 75005 Paris, France.

2. Historic Environment Department, Department of Culture and Tourism (DCT), Nation Towers Corniche, PO Box 94000, Abu Dhabi, UAE.

Corresponding author: Kevin Lidour, lidour01@gmail.com

Highlights

- Ospreys are reported to build nests and to perch on archaeological sites.

- The impact of ospreys on archaeological fish bone assemblages is assessed.

- Almost 2000 modern prey remains have been collected close to osprey's perches.

- The taphonomic signature of the osprey has been described.

- Ospreys are not accumulation agents at archaeological sites on Marawah Island

\section{Abstract}

The Osprey Pandion haliaetus is one of the most widely distributed raptor species in the world, present on all continents except Antarctica. Since its diet is mainly based on fish, this raptor is typically encountered close both to marine and fresh waters. Ospreys are well represented in the Arabian Peninsula where remote islands are the location for some of their key breeding sites. On Marawah Island (Emirate of Abu Dhabi, United Arab Emirates), ospreys have been reported to build nests on top of abandoned man-made structures, including archaeological sites. The discovery of fish remains associated with numerous bird bones and eggshell fragments in archaeological deposits raises the question of the potential contamination of ancient faunal accumulations by birds of prey. To date, the possible impact of ospreys on zooarchaeological assemblages has been little 
considered and the taphonomic signature of this fish-eating raptor has never been described. However, ospreys are effective competitors to traditional and small-scale fisheries and should be considered as potential accumulators of fish remains on archaeological sites located close to water bodies. Indeed, zooarchaeological analyses demonstrate that fish had always played a major role in the daily subsistence of the ancient inhabitants of Marawah Island since the first traces of occupation dating back some 8000 years. The present study will enable researchers working in the region as well as in other geographical area to determine if ospreys are accumulation agents for fish remains on archaeological sites.

The present diet assessment of ospreys allows us to specify the taphonomic signature of this raptor: targeted species are mainly medium to large-sized fish swimming just beneath the surface (e.g. needlefish and queenfish) and slow benthic fish occurring in shallow waters such as tripodfish, emperors, and groupers. Bone accumulations are almost entirely composed of skull elements, indicating specific discarding behaviours. Certain traces left on jaw bones, in particular maxillae, can also help to differentiate osprey accumulations from archaeological ones.

Keywords: Osprey; Pandion haliaetus; Fish bones; Taphonomy; Coastal archaeology; Ecosystem connectivity

\section{Introduction}

The osprey (Figure 1) is a worldwide spread raptor whose diet is almost entirely based on fish (Evans, 1982; Poole, 1989; Mackrill, 2019). Ospreys also occasionally eat small mammals (e.g. muskrats), rabbits, hares, reptiles, as well as other birds such as seagull and waterfowl when fish are not available (Dmokhovskiy, 1933; Gusev \& Chueva, 1951). It is thus typically nesting in the open air, near water bodies - both fresh and salt. Ospreys can reach up to $60 \mathrm{~cm}$ in length by 150 to $180 \mathrm{~cm}$ wingspan. Adult specimens usually weigh between 1.2 and $2 \mathrm{~kg}$. They build very distinctive tower-like nests with scrubs, branches, and driftwoods (Figure 2.B) seaweed and dead sea sponges are often used as bedding. Foraging flights can cover several kilometres - usually between 3 and $6 \mathrm{~km}$, up to $14 \mathrm{~km}$ (Flemming \& Smith, 1990). While ospreys mostly catch fish with their claws by flying just over the surface of the water, they are able to dive to a depth not exceeding $1 \mathrm{~m}$. According to Clancy (2005), the possible consumption of discarded fish originating from human fishing activities is highly uncertain. 


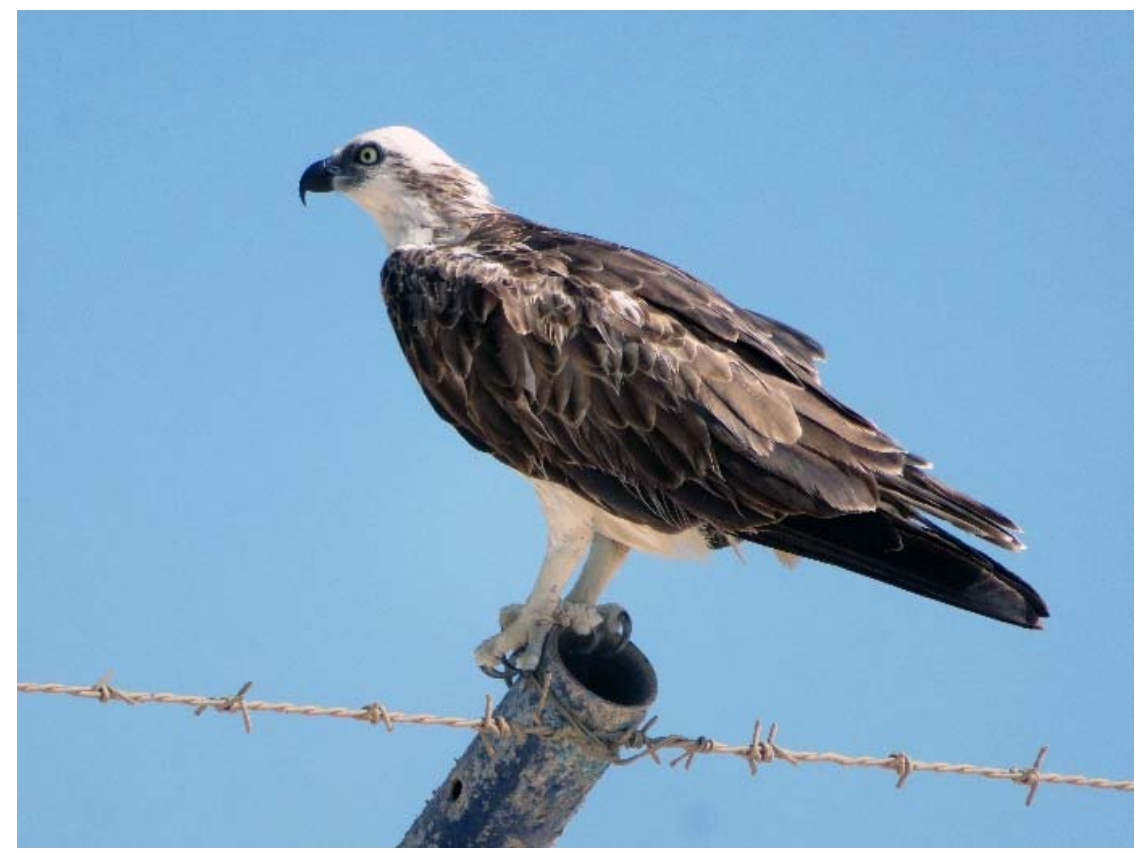

Figure 1. Osprey (Pandion haliaetus) perching on an army military fence at Ra's Ghumais, Emirate of Abu Dhabi (C R. Cuttler, 2019).

Important populations of ospreys breed in the Arabian Peninsula, mostly in the United Arab Emirates, Bahrain, and the Sultanate of Oman (Khan et al., 2007). They usually nest between November and April, when they can be supplemented by migrants and winter individuals. Nevertheless, individuals can be also observed throughout the year in the region (Aspinall, 1996). Populations in the Northern Hemisphere migrate over long-distance seasonally whereas individuals living at lower latitudes are almost sedentary, or involved in short distance interbreeding movements (Poole, 1989; Thibault et al., 1996). A recent study conducted in the Emirate of Abu Dhabi (Khan et al., 2015), has pointed out that remote islands are preferred by ospreys to nest since they are relatively isolated from human activities. 


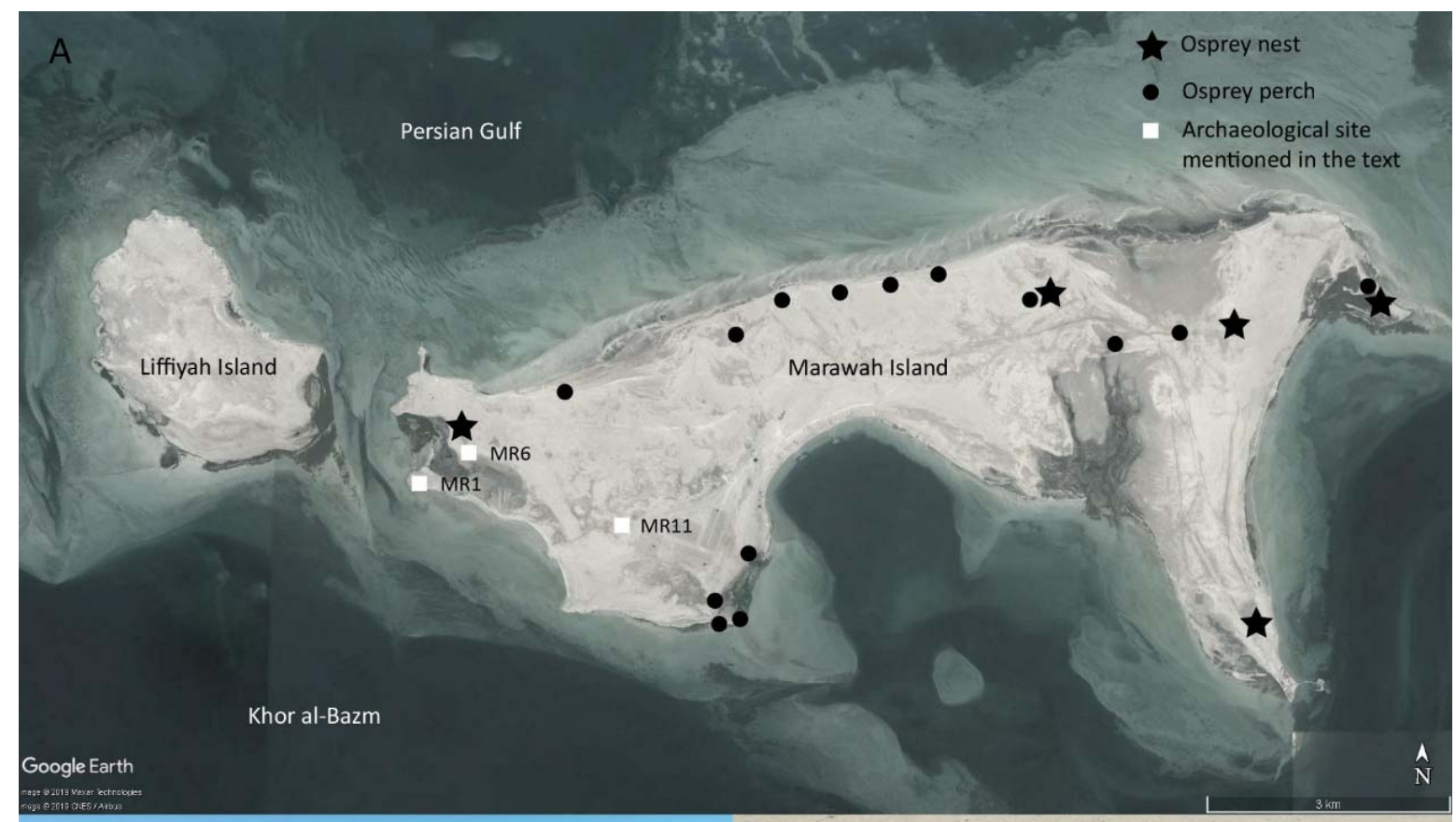

B

C

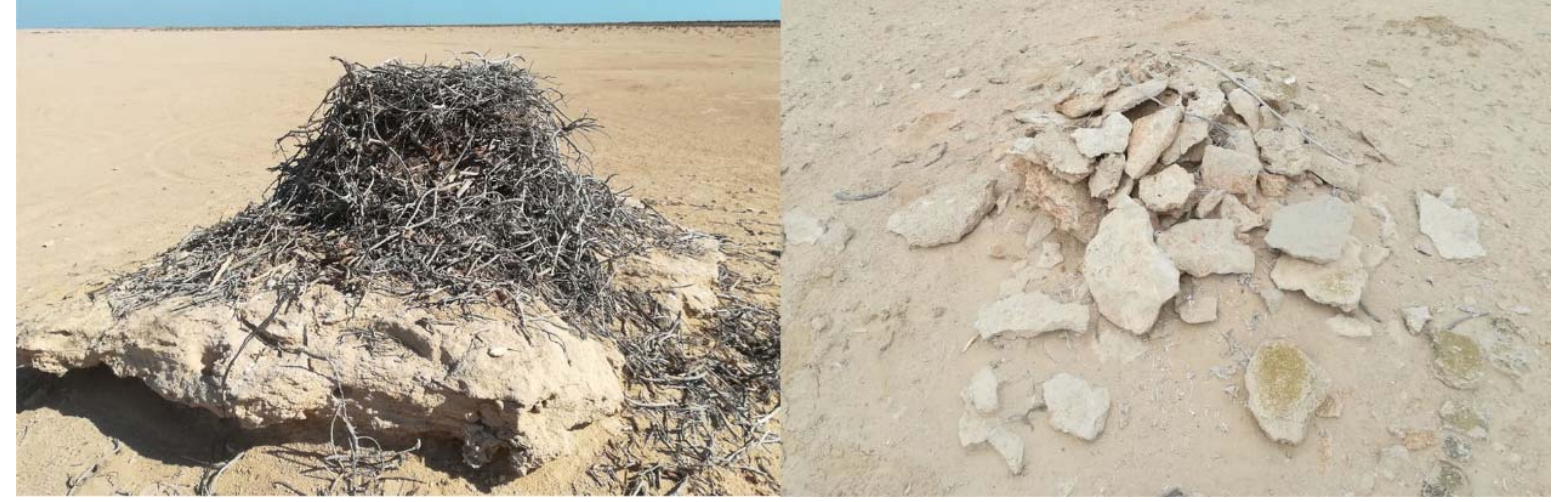

Figure 2. A. Map of Marawah Island showing the location of the osprey nests and perches investigated (Image (C) Google Earth \& Maxar Technologies, 2019); B. Osprey tower-like nest in brushwood built on a small natural platform, Marawah Island (C K. Lidour, 2019); C. Osprey perch on the top of a small stone mound, Marawah Island (C K. Lidour, 2019). 


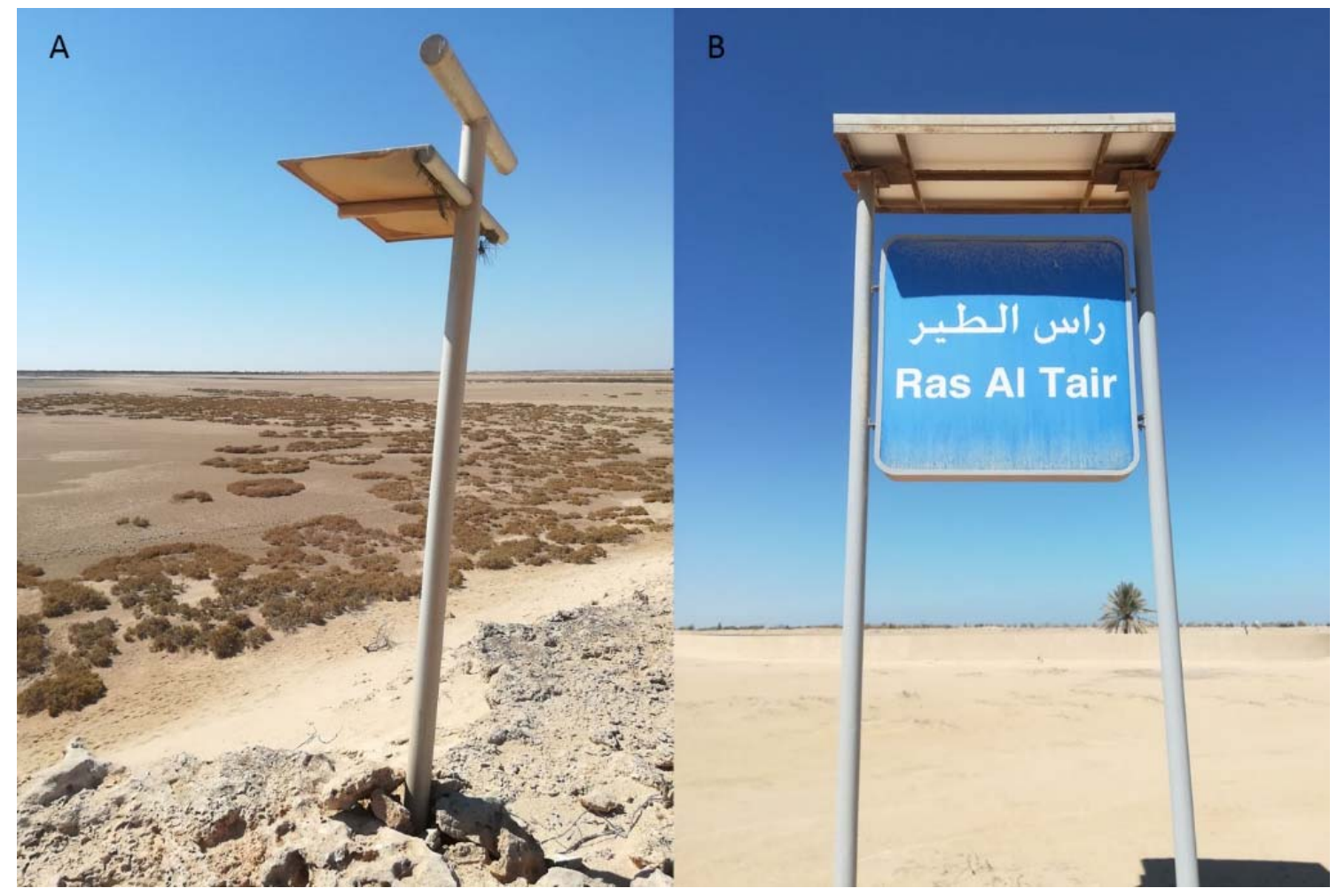

Figure 3. A. Artificial platform installed for osprey perching, Marawah Island (C) $\mathrm{K}$. Lidour, 2019); B. Signal with solar panel used as perch by ospreys, Marawah Island (C K. Lidour, 2019).

\section{Area study and archaeological setting}

Marawah Island lies about $15 \mathrm{~km}$ off the main coastline of the Emirate of Abu Dhabi, measuring about $4 \mathrm{~km}$ from North to South by $14 \mathrm{~km}$ from East to West (Figure 2.A). The island is formed of several low limestone platforms separated by sand deposits and salt flats. The vegetation is mainly composed of glasswort (mostly Chenopodiaceae) and spiny bushes (e.g. Sphaerocoma aucheri). The shorelines are dominated by sand beaches and a few mangrove stands. The nearest seabed is shallow and characterized by fringing reefs and tidal ridges occupied by extensive seagrass and macroalgae beds. The surrounding marine environment also hosts sparse coral patches which are essentially composed of Porites species. Since 2007, the Marawah Marine Biosphere Reserve covers a protected area of 425,000 ha and hosts rich wildlife, including several flagship species such as marine turtles and dugongs.

While the island is nowadays inhabited by a few people for part of the year, ancient human occupations are well documented with some sites, such as MR1 and MR11, dating back to the Neolithic period, from at least 8000 years ago (King, 1998; Beech et al., 2005, 2019). Zooarchaeological studies have revealed the importance of fish in the diet of the ancient inhabitants of the island (Beech, 2004: 124-140; Lidour \& Beech, 2019). The site of MR11 Area $A$ is famous for its original tripartite stone-built house and the complete Mesopotamian pottery vessel discovered inside it. Radiocarbon datations indicate that the site was inhabited between the first half of the $6^{\text {th }}$ and the middle of the $5^{\text {th }}$ millennium BCE. Since 2017, excavations at MR11 have been extended to a new area (Area C) where further stone 
structures have been discovered (Beech et al., 2016, 2019). A great number of faunal remains have been recovered and are currently under study. The assemblage is mainly composed of fish bones and seashells, a few dugong and turtle bones, and more surprisingly, an important number of bird remains and eggshell fragments. There are historical accounts on the Abu Dhabi islands of local people collecting bird eggs for food. These primarily seem to have been cormorant and tern eggs which are available in great abundance in some of the colonies on the offshore islands. In fact, at MR11, bird remains are mostly concentrated in the latter contexts, associated with rubble deposits. Hence, one can expect that the stone structures were re-occupied by wildlife after their abandonment.

Indeed, since natural outcrops are quite rare on Marawah, some of the archaeological stone structures (houses, tombs, kilns, and landmarks) were probably used as perching points by birds of prey (Beech, 2003). We must consider that archaeological sites such as MR11 Area C could have been contaminated by fish bones that do not result from anthropogenic related activities. The impact of raptors on the archaeological accumulations has been frequently pointed out, in particular in cave and rock shelter contexts (Russ \& Jones, 2011). Indeed, raptors often share some of the same fish taxa that humans exploit. Comprehensive studies of the raptors diet and of the taphonomy of the prey remains collected from nests, perches, and pellets can allow a clear assessment of the impact of ichthyophagous birds on the archaeological faunal assemblages (Russ, 2010; Broughton et al., 2006; Erlandson et al., 2007; Guillaud et al. 2018; Guillaud et al., 2019).

The present study focuses on the diet of the osprey Pandion haliaetus (Linnaeus, 1758) which is the main ichthyophagous raptor encountered on Marawah Island and therefore a potential accumulation species for fish remains on archaeological sites. Its principal aims are :

- To assess the dietary behaviour of the osprey on Marawah Island in terms of target species, size ranges, discarding methods, and type of traces left on the discarded remains;

- To compare it with archaeological assemblages and determine the features allowing to differentiate fish remains accumulations originated from human and osprey activities.

An understanding of the feeding and discarding behaviors of ospreys on Marawah Island is essential to evaluate the possible contamination of the MR11 faunal assemblage.

\section{Material and methods}

Two distinct methods have proven successful for the assessment of the osprey diet. The observation (direct or recorded) of birds during their foraging flights (e.g. Eriksson, 1986; Glass \& Watts, 2009; Clancy, 2005; Marquiss et al., 2007; Galarza, 2010) and the taxonomical determinations of prey remains collected under nests and perches (e.g. Carss \& Brockie, 1994; Francour \& Thibault, 1996; Beech, 2003). Ospreys tear the flesh off the bodies of their preys. Since only a few small and broken bones are usually swallowed, pellets could not be used in the study of the osprey diet unlike for other fish-eating raptors such as owls and seagulls 
(Prevost, 1982: 85; Fisher, 2001: 206). It was observed that, at Marawah, ospreys generally do not eat fish in their nest but almost exclusively on perches, around which numerous fish remains were collected.

Both nests and perches were located and investigated during our field study at Marawah (February-March 2019) (Figure 2.A). Active nests found with nestlings inside were not disturbed. Perches are of three types: natural rocky outcrops, walls or artificial piles of rocks (Figure 2.C), and modern poles and signals which are generally equipped with small solar panels where ospreys roost (Figure 3). Discarded bones were collected in bulk samples with sediment. Then, the samples were dry sieved at the field house using a $2 \mathrm{~mm}$ wire mesh sieve. The remains were almost entirely collected on the ground surface and thus highly affected by post-depositional phenomenons such as weathering (indicated by bleaching and cracking) and possible scavenging activities. Note that the use of special installations such as the hanging of wire mesh baskets under the perches has been suggested by Prevost (1982: 85-87, fig. 3.1), to protect the dropped remains from scavengers.

Anatomical and taxonomical identifications were conducted according to the methods of comparative anatomy, using the reference collection of the National Museum of Natural History, Paris. Quantifications were based on methods used in palaeontology and zooarchaeology. NISP stands for 'number of identified specimens', MNI for 'minimum number of individuals', and WISP for 'weight of identified specimens'. MNI quantifications are calculated according to the combination method: the frequency of bones is combined with laterality and size estimations (Chaplin, 1971). Precise determinations of the length and the weight of prey specimens were especially conducted on spangled emperors (Lethrinidae) remains since an osteometric model (using allometric relationship equations) is available for this species (Lidour et al., 2018). Measurements were taken with a digital calliper with a precision of two decimal points and registered in a Microsoft Excel spreadsheet. For the other taxa, average lengths and weights were made after visual comparisons of archaeological bones with reference specimens (Wheeler \& Jones, 1989: 141).

\section{Results}

\section{Taxonomic spectrum}

Only a few fish remains were found inside the nests $(N=13)$. They include otoliths which could have resisted digestion and originated from osprey droppings. Such otoliths are frequently highly polished due to the action of gastric fluids. These results clearly contrast with observations made in other area such as in the Farasan Archipelago in the Red Sea, where 45\% of the fish remains were collected in nests (Fisher, 2001: 118). In our study, fish remains were almost entirely collected around the perches - they were mostly found in a radius of $1.5 \mathrm{~m}$ around these locations. Fish remains not only included bones but also some pieces of dried skin (not recorded). A Socotra cormorant (Phalacrocorax nigrogularis) tibiotarsus was also found in a perch sample. Some studies have pointed out the presence of other birds, small reptiles, amphibians, and mammals in osprey diet (e.g. Karjakin, 1998: 8, table P-1; Ivanovski, 2012: 25). Interestingly, Dmokhovskiy (1933: 223) has directly observed that ospreys 
sometimes hunt seagulls (Larus heuglini) in northwest Russia (Pechora River). However, the discovery of a single cormorant bone in our assemblage is not sufficient to support the hypothesis that ospreys hunt cormorants on Marawah Island. Therefore, it is likely that this bone is of an intrusive nature. As a matter of fact, the tibiotarsus does not show any beak or talon marks similar to those caused by other raptors (e.g. Lloveras et al. 2014).

A few desert locust (Schistocerca gregaria) legs and wings were also identified from one of the nest samples. A few blue crab (Portunus segnis) remains could be attributed to osprey predations since this species cannot be encountered out of the water. Similarly, red rock crabs (Grapsus grapsus) were identified by Siverio et al. (2011) at two perches on Tenerife Island (Canarian Archipelago) but they were not considered consumed by ospreys by the latter authors. A few fragments of isopod exoskeletons were also found.

An earlier investigation has described the short-nosed tripodfish (Triancanthus biaculeatus) as the main prey of ospreys at Marawah (Beech, 2003). The present study provides a more complete view of the diet of this raptor (Figure 4). A total of 1950 anatomical items were collected of which 1559 (almost 80\%) were successfully attributed to family, genus or species level (Table 1). A minimum total of 235 individuals (MNI) were recorded. Despite the large assemblage studied and the low rate of undetermined specimens, only 12 distinct fish taxa were identified. They are, in order of importance of the NISP: tripodfish (Triacanthidae), emperors (Lethrinidae), needlefish (Belonidae), jacks and trevallies (Carangidae), groupers (Serranidae), angelfish (Pomacanthidae), mojarras (Gerreidae), rabbitfish (Siganidae), flatheads (Platycephalidae), seabreams (Sparidae), and halfbeaks (Hemiramphidae).

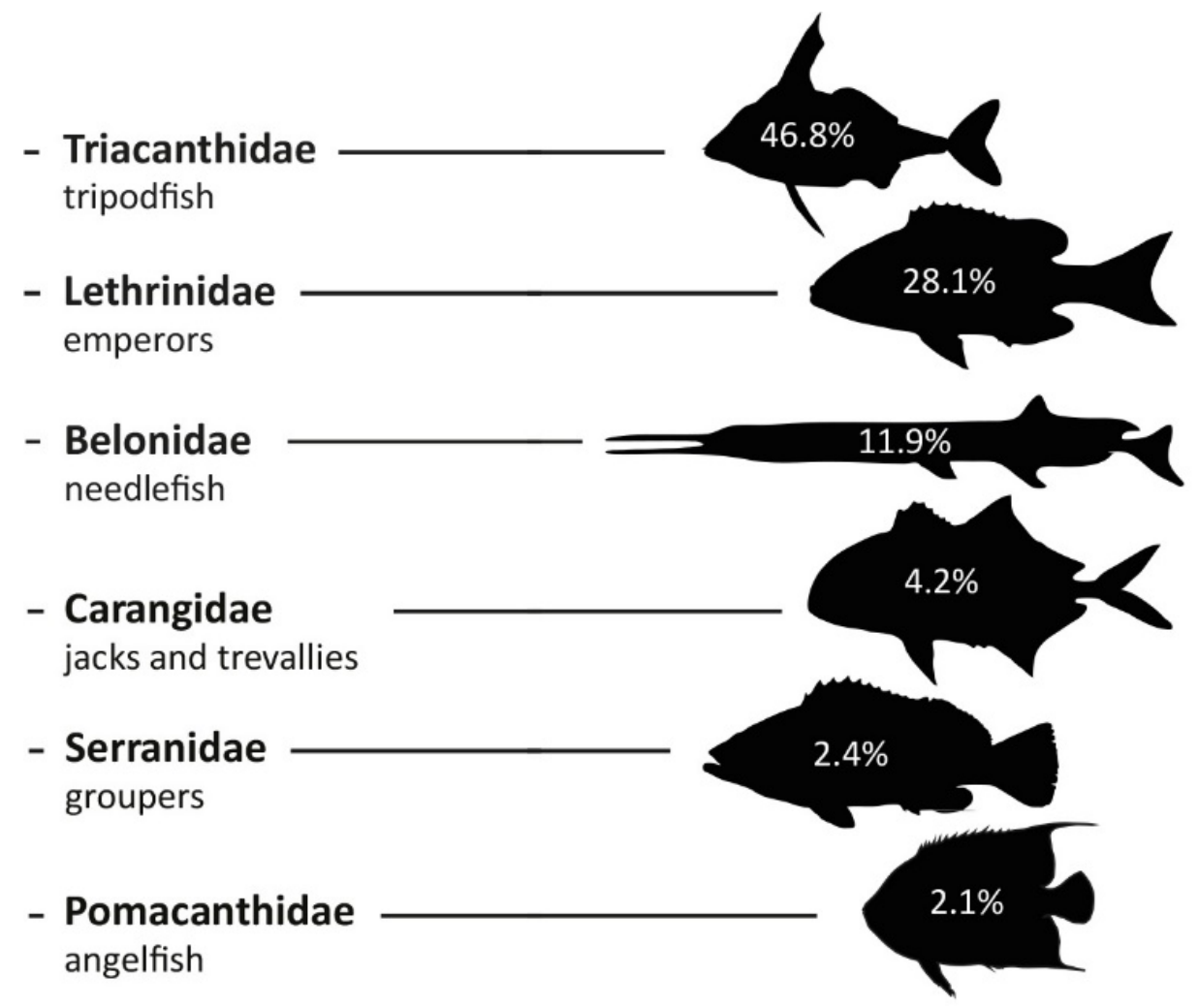

Figure 4. Main fish families caught by ospreys on Marawah Island. NISP = 1559. Others $=4.5 \%$ 
On the basis of NISP, almost $80 \%$ of the studied assemblage is composed of short-nosed tripodfish (36.6\%), spangled emperors (Lethrinus nebulosus) (26.8\%), and houndfish (Tylosurus spp.) (11.7\%). Other main taxa include small queenfish (Scomberoides sp.) (4.2\%), groupers (Epinephelus spp.) (2.4\%), and the yellowbar angelfish (Pomacanthus maculosus) (2.1\%).

\begin{tabular}{|c|c|c|c|c|c|}
\hline Family & Genus & Species & NISP & MNI & $\begin{array}{l}\text { WISP } \\
\text { (g) }\end{array}$ \\
\hline $\begin{array}{l}\text { Hemiramphida } \\
\text { e }\end{array}$ & Hemiramphus & Hemiramphus sp. & 2 & 2 & 0.5 \\
\hline \multirow[t]{3}{*}{ Belonidae } & Tylosurus & Tylosurus choram & 2 & 2 & 0.12 \\
\hline & & Tylosurus sp. & 180 & 34 & 98.0 \\
\hline & ind. & & 5 & - & 0.5 \\
\hline $\begin{array}{l}\text { Platycephalida } \\
\text { e }\end{array}$ & Platycephalus & Platycephalus indicus & 10 & 8 & 2.86 \\
\hline \multirow[t]{3}{*}{ Serranidae } & Epinephelus & Epinephelus coioides & 1 & 1 & 0.52 \\
\hline & & Epinephelus sp. & 37 & 5 & 10.07 \\
\hline & ind. & & 10 & 1 & 2.5 \\
\hline Carangidae & Scomberoides & Scomberoides sp. & 65 & 14 & 6.8 \\
\hline Gerreidae & Gerres & Gerres sp. & 12 & 6 & 1.88 \\
\hline \multirow[t]{2}{*}{ Lethrinidae } & Lethrinus & Lethrinus nebulosus & 418 & 52 & 194.61 \\
\hline & & Lethrinus sp. & 20 & - & 5.16 \\
\hline \multirow[t]{3}{*}{ Sparidae } & $\begin{array}{l}\text { Acanthopagru } \\
s\end{array}$ & Acanthopagrus bifasciatus & 2 & 1 & 1.81 \\
\hline & Rhabdosargus & Rhabdosargus haffara & 7 & 4 & 2.24 \\
\hline & ind. & & 14 & - & 2.12 \\
\hline $\begin{array}{l}\text { Pomacanthida } \\
\text { e }\end{array}$ & Pomacanthus & Pomacanthus maculosus & 33 & 19 & 9.92 \\
\hline Siganidae & Siganus & Siganus sp. & 10 & 2 & 0.53 \\
\hline \multirow[t]{2}{*}{ Triacanthidae } & Triacanthus & Triacanthus biaculeatus & 571 & 84 & 190.75 \\
\hline & ind. & & 160 & - & 40.66 \\
\hline \multirow[t]{3}{*}{ ind. Teleostei } & & & 391 & - & 74.83 \\
\hline & & Total determined & 1559 & 235 & 571.55 \\
\hline & & Grand Total & 1950 & 235 & 646.38 \\
\hline
\end{tabular}

Table 1. Table of identified fish from the nests and perches investigated. Quantifications in NISP, MNI and WISP.

\section{Size estimations}

Size estimations were conducted on 630 prey items. Visual estimations with reference specimens indicate that fish which were eaten ranged from 15 to $80 \mathrm{~cm}$ in length (total length) 
- that is roughly from $80 \mathrm{~g}$ to $1 \mathrm{~kg}$. Needlefish are the longest fish recorded: specimens mainly range between 60 and $80 \mathrm{~cm}$ ( 400 to $1000 \mathrm{~g}$ ). Queenfish are estimated to be between 35 and $50 \mathrm{~cm}$ ( 250 to $800 \mathrm{~g}$ ). Groupers are mainly comprised between 23 and $36 \mathrm{~cm}$ (200 to $850 \mathrm{~g}$ ), flatheads about $40 \mathrm{~cm}(400 \mathrm{~g})$, and angelfish from 25 to $32 \mathrm{~cm} \mathrm{(450} \mathrm{to} 950 \mathrm{~g})$. Mojarras are mostly about $28 \mathrm{~cm}(400 \mathrm{~g})$. The smallest fish recorded are rabbitfish which comprised between 15 and $22 \mathrm{~cm}$ ( 80 to $120 \mathrm{~g}$ ). Given the small number of collection specimens of tripodfish that we can access, precise estimations of both length and weight were not conducted for this species. However, short-nosed tripodfish commonly measure about $25 \mathrm{~cm}$ in length, up to $30 \mathrm{~cm}$ (Hutchins, 1984) - $130 \mathrm{~g}$ in mean and up to $230 \mathrm{~g}$, according to Karna et al. (2018).

More precise length and weight reconstructions were conducted for the spangled emperors using an osteometrical model (Lidour et al., 2018) (Figure 5). Measurements with coefficient of determination $\left(r^{2}\right)$ below 0.95 were not used. Nevertheless, valid measurements were possible on 312 remains (almost 75\% of the recorded remains for this species). They were mainly conducted on angulo-articulars, premaxillae, maxillae, dentaries, and palatines. Given the unquantifiable bias caused by taphonomic processes, MNI calculations were not taken into account for these size reconstructions (Grayson, 1984). Results indicate that specimens ranged from 21 to $51 \mathrm{~cm}$ in length, which could be converted with the length-weight relation given in the same study (Ibid: fig. 4; tab. 2): from 135 to $1850 \mathrm{~g}^{1}$. However, most of the specimens are comprised between 30 and $35 \mathrm{~cm}$ in length (395 and $620 \mathrm{~g}$ ). Similar results were obtained by applying the Global Rachidian Profiles (Ibid: fig. 6). M2 measurements on vertebrae (i.e. maximum width of the centrum) are compatible with a reference specimen of $33 \mathrm{~cm}$. It is noteworthy that osteometric studies allow us to specify the wide range of fish sizes caught by ospreys.
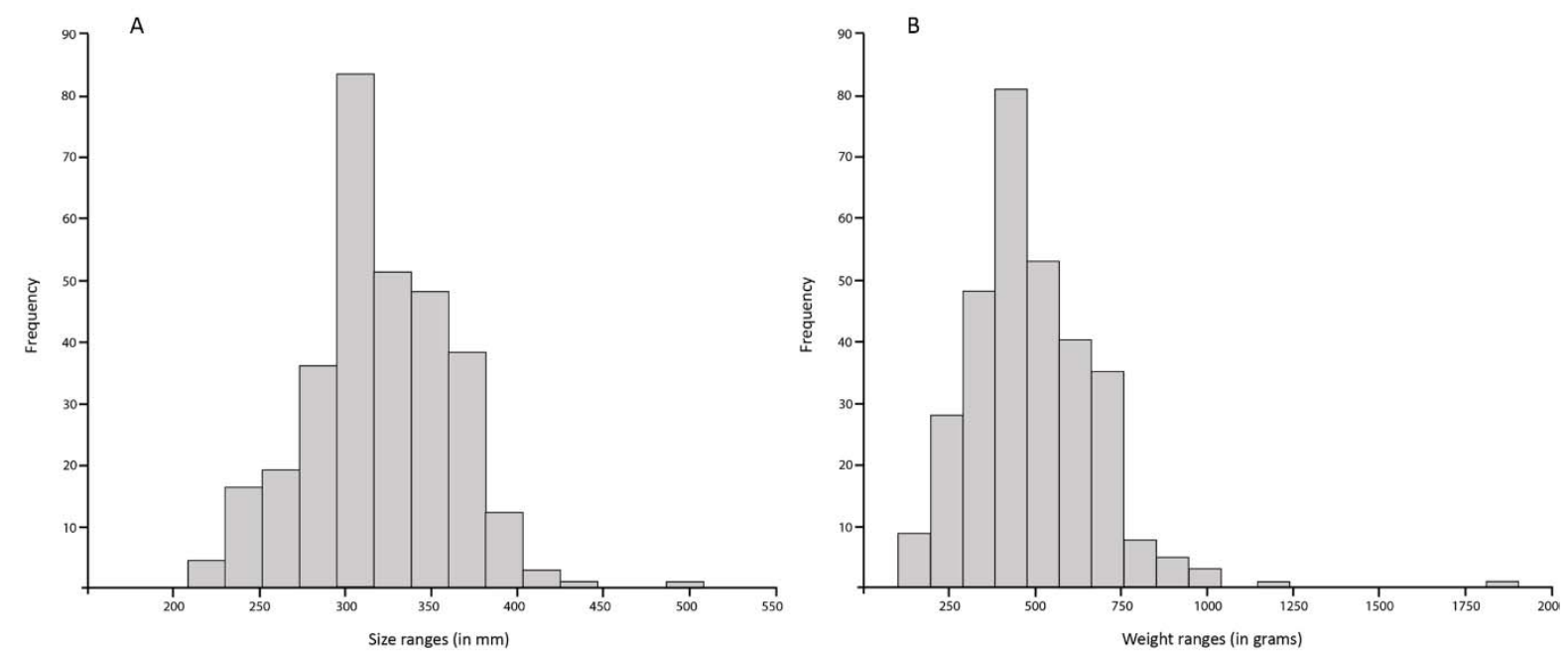

Figure 5. A. Histogram plot of reconstructed lengths of spangled emperors (Lethrinus nebulosus) caught by ospreys on Marawah Island ( $\mathrm{N}=312)$; $\mathrm{B}$. Corresponding reconstructed weights.

\footnotetext{
${ }^{1} A$ total length of $507 \mathrm{~mm}$ was obtained from a measurement of an emperor dentary (Dentary $\mathrm{M} 1, \mathrm{r}^{2}=0.9501$ ). Conversion with a length to weight equation in the form $y=a .{ }^{b}\left(r^{2}=0.9875\right)$ was then conducted and gave a fresh weight of $1850 \mathrm{~g}$.
} 


\section{Anatomical representation}

While the vertebrae slightly predominate the assemblage (20.8\%), the anatomical items derived from the skull are also quite well represented: premaxillae (16\%), dentaries $(10.2 \%)$, preopercles (6.7\%), maxillae (4.1\%), and angulo-articulars (4\%) (Table 2) (Figures 5-6). More remarkable pieces were recorded, such as tripodfish fused snouts (composed of prefrontals, ethmoids, and the vomer which are strongly ossified and fused) (Tyler, 1980: 32) (Figure 6 $\left.\mathrm{n}^{\circ} 10\right)$. It is likely that for the biggest specimens, frontals tend to fuse with them. We also observed that dentaries are sometimes fused. Examples were previously found in an archaeological context at Akab, a Neolithic site in the Emirate of Umm al-Quwain (northern UAE) (Lidour, 2018: fig. 6.1.12 n¹3-15; Lidour et al., 2019).

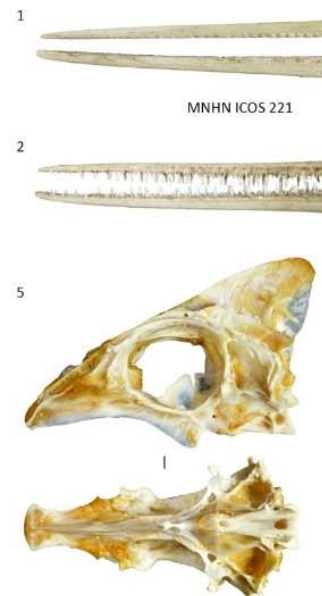

MNHN ICOS 1333

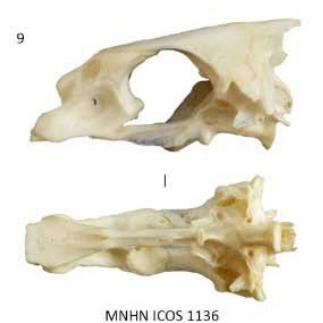

MNHNICOS 1136
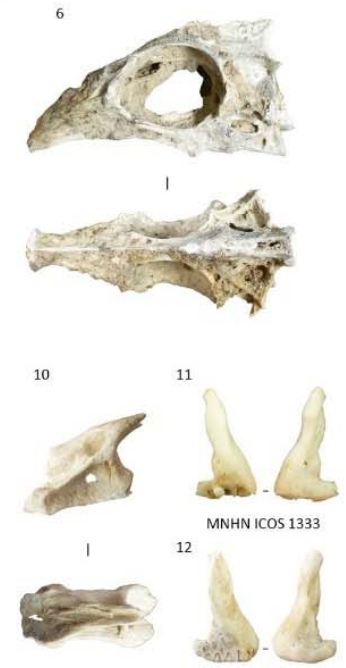
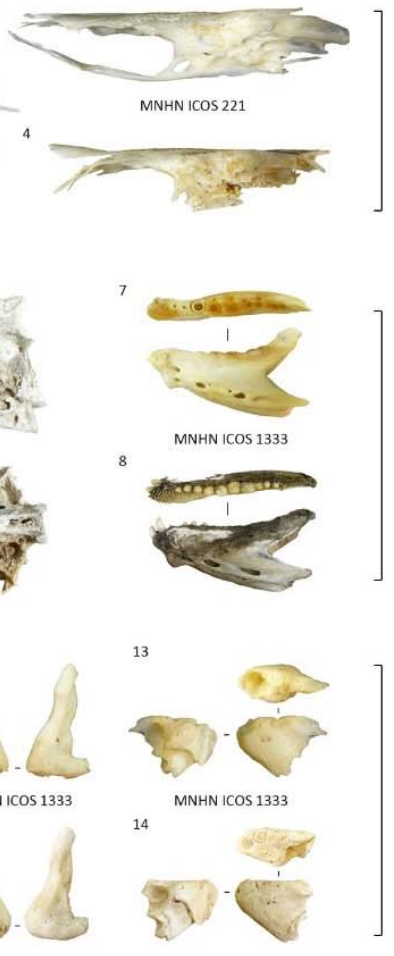

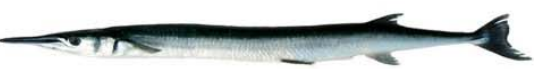

Belonidae: Tylosurus choram (Rüppell, 1837) (Red Sea houndfish)

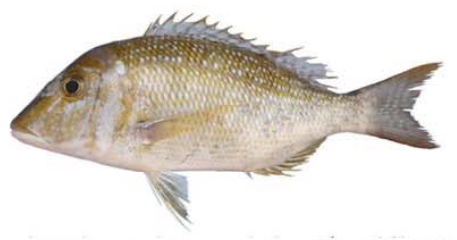

Lethrinidae: Lethrinus nebulosus (Forskål, 1775) (Spangled emperor)

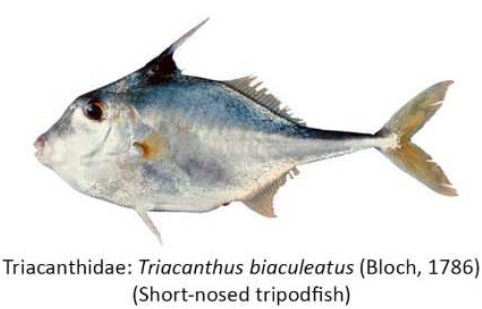

Figure 6. Sample of prey remains compared to analogue bones from the MNHN osteological reference collection, and corresponding live pictures of the species (@ K. Lidour, P. Béarez, CSIRO CC-BY-NC): 1-2. Left premaxillae and dentaries of Red Sea houndfish, Tylosurus choram; 3-4. Neurocrania of Red Sea houndfish, Tylosurus choram; 5-6. Neurocrania of spangled emperor, Lethrinus nebulosus; 7-8. Left dentaries of spangled emperor, Lethrinus nebulosus; 9. Neurocranium of short-nosed tripodfish, Triacanthus biaculeatus; 10. "Fused snout" (vomer, ethmoids, and prefrontals) of short-nosed tripodfish, Triacanthus biaculeatus; 11-12. Left premaxillae of short-nosed tripodfish, Triacanthus biaculeatus; 1314. Left dentaries of short-nosed tripodfish, Triacanthus biaculeatus. Scale: $1 \mathrm{~cm}$ 

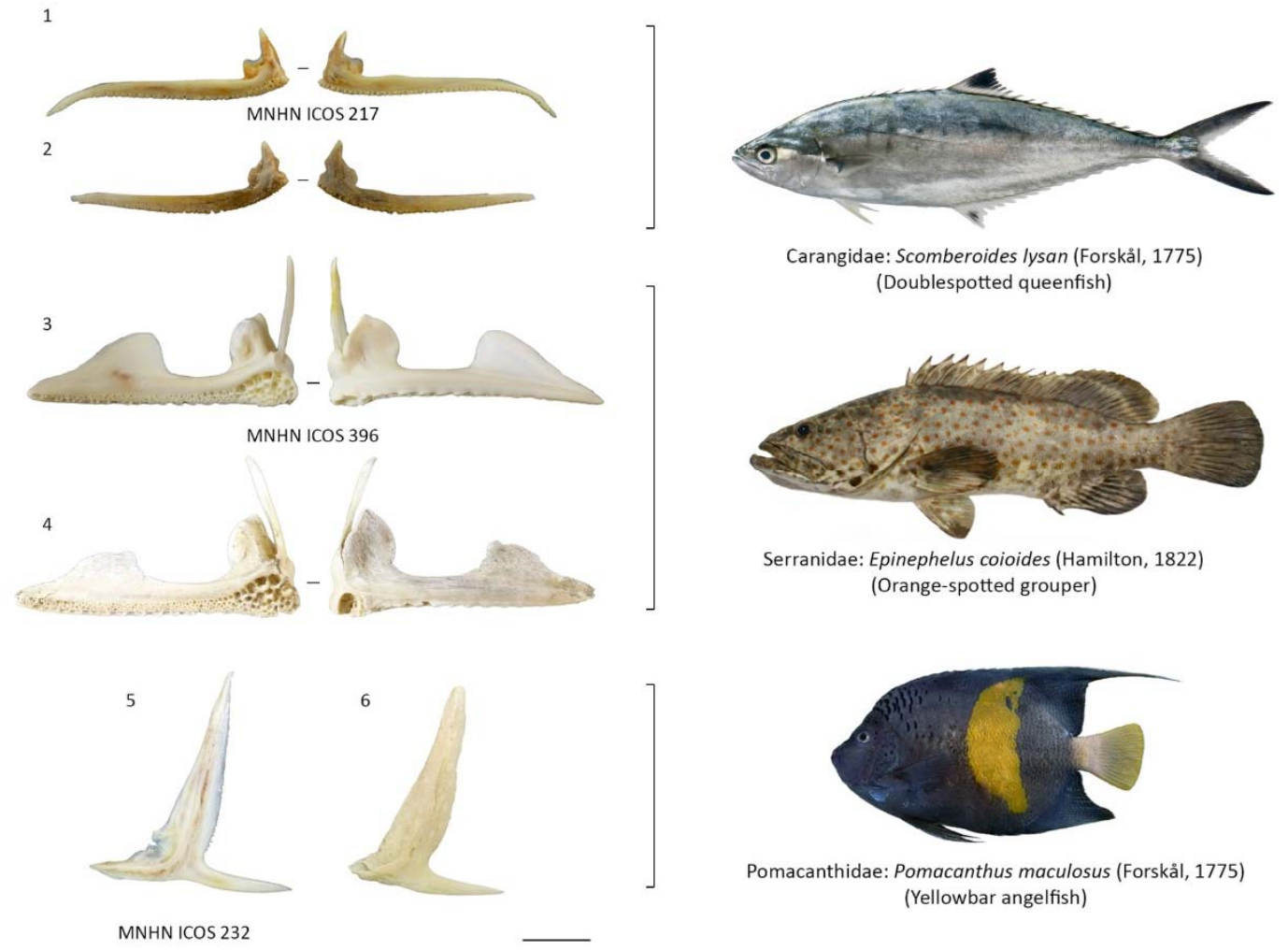

Figure 7. Sample of prey remains compared to analogue bones from the MNHN osteological reference collection, and corresponding live pictures of the species (C K. Lidour, P. Béarez, CSIRO CC-BY-NC): 1-2. Left premaxillae of doublespotted queenfish, Scomberoides lysan: 34. Left premaxillae of orange-spotted grouper, Epinephelus coioides: 5-6. Left preopercles of yellowbar angelfish, Pomacanthus maculosus. Scale: $1 \mathrm{~cm}$

\begin{tabular}{|c|c|c|c|c|c|c|c|c|}
\hline & \multicolumn{2}{|c|}{ Teleostei } & \multicolumn{2}{|c|}{ T. biaculeatus } & \multicolumn{2}{|c|}{ Lethrinus spp. } & \multicolumn{2}{|c|}{ Tylosurus spp. } \\
\hline & NISP & $\%$ & NISP & $\%$ & NISP & $\%$ & NISP & $\%$ \\
\hline Vomers & 5 & & & & 3 & & & \\
\hline Frontals & 46 & & 28 & & 18 & & & \\
\hline Parasphenoids & 4 & & & & 4 & & & \\
\hline Basioccipitals & 2 & & 1 & & 1 & & & \\
\hline Otoliths & 6 & & & & 4 & & & \\
\hline Fused snout & 68 & & 68 & $11.9 \%$ & & & & \\
\hline Neurocrania & 39 & & 32 & $5.6 \%$ & 5 & & 2 & \\
\hline Palatines & 34 & & 6 & & 27 & $6.2 \%$ & & \\
\hline Maxillae & 74 & & 16 & & 42 & $9.6 \%$ & & \\
\hline Premaxillae & 286 & $16.0 \%$ & 110 & $19.3 \%$ & 80 & $18.3 \%$ & 65 & $35.7 \%$ \\
\hline Dentaries & 182 & $10.2 \%$ & 27 & & 64 & $14.6 \%$ & 72 & $39.6 \%$ \\
\hline Angulo-articulars & 72 & & 8 & & 44 & $10 \%$ & 6 & \\
\hline Quadrates & 25 & & 11 & & 11 & & & \\
\hline Hyomandibulas & 22 & & 2 & & 18 & & & \\
\hline
\end{tabular}




\begin{tabular}{l|cccccccc} 
Opercles & 21 & & 3 & & 15 & & & \\
Preopercles & 121 & $6.7 \%$ & 57 & $10 \%$ & 31 & $7.1 \%$ & & \\
Cleithra & 13 & & 2 & & 9 & & & \\
Other cranial bones & 43 & & & & 20 & & 20 & $11 \%$ \\
Pelves & 6 & & 6 & & & & & \\
Rays and spines & 319 & $17.8 \%$ & & & & & & \\
Pterygiophores & 28 & & & & & & & \\
Scales & 4 & & & & & & & \\
Vertebrae & 373 & $20.8 \%$ & 194 & $34 \%$ & 42 & $9.6 \%$ & 17 & \\
Ind. & 157 & & & & & & & \\
& & & & & & & & \\
Total NISP & 1793 & & 571 & & 438 & & & \\
Grand total & 1950 & & & & & &
\end{tabular}

Table 2. Distribution of anatomical elements for some of the main taxa identified.

\section{Discussion}

\section{Ecology of the main fish taxa recorded}

The short-nose tripodfish is a small triacanthid fish, closely related to triggerfish (Balistidae) (Tyler, 1980: 131). It typically occurs in inshore environments with soft substrate and brackish waters, such as estuaries and mangroves (Randall, 1995: 391). The spangled emperor is one of the commonest species of emperor occurring in the Arabian/Persian Gulf. It is encountered in a variety of coastal habitats within both soft and hard bottom areas, including coral reefs (Laboute \& Grandperrin, 2006: 327). However, juveniles mainly inhabit shallow sheltered waters where extensive seagrass and algal beds occur. It is assumed that mature individuals aggregate close to these environments during the spawning season, which occur in spring (Egretaud, 1992). Traditional fisheries generally focus on individuals about 20-50 cm in length, but largest specimens are reported to reach up to $80 \mathrm{~cm}$ (Carpenter et al., 1997: 184). The Red Sea houndfish (Tylosurus choram) is reported as a coastal species whereas the hound needlefish (Tylosurus crocodilus) could be found offshore (Randall, 1995: 87). However, both the taxonomy and the ecology of needlefish remain broadly misunderstood (Parin, 1967). Needlefish generally swim close to the surface solitary or in small schools for hunting smaller fish occurring in the epipelagic zone. It is likely that most of the needlefish remains recorded from Marawah belong to the Red Sea houndfish. Specimens can reach $120 \mathrm{~cm}$ in length, but are commonly about $60-80 \mathrm{~cm}$ (up to $1 \mathrm{~kg}$ ) (Golani et al., 2002).

Among the other main taxa identified, the yellowbar angelfish and the orange-spotted grouper (Epinephelus coioides) are fish mainly associated with silty reef areas (Sommer et al., 1996: 269; Lieske \& Myers, 1994). The recorded queenfish remains are closer to the doublespotted queenfish (Scomberoides lysan) than to other queenfish species encountered 
in the area. Doublespotted queenfish is abundant in the Indian Ocean, especially in shallow and clear coastal waters (Smith \& Heemstra, 1985: 655).

\section{Taxonomic diversity and feeding behaviors}

The poor diversity in the catch of osprey at Marawah is strikingly contrasting with the assemblages studied by Fisher (2001) and Safriel et al. (1985) from the Red Sea, where more than fifty distinct taxa have been reported (Table 3). According to Eadgeri et al. (2019), the ichthyological diversity in the Arabian/Persian Gulf is about 744 species while the Red Sea is home to at least 1078 species (Golani \& Bogorodski, 2010). Extreme conditions of temperature and salinity that occur in the Arabian/Persian Gulf are considered to be direct causes of reduced levels of taxonomic richness (Price, 2002). The ichthyological diversity is even lower along the coast of the UAE with only 227 species recorded by Shallard et al. (2003). There is thus no doubt that the number of fish taxa available in the local waters has a direct impact on the osprey dietary diversity (Fisher, 2001: 122). Hence, the diversity of prey species is significantly higher in tropical areas than in Europe and Northern America.

Fish which are feeding or remaining near the surface such as needlefish, halfbeaks and queenfish are easier to detect from the air and thus easy to catch for ichthyophagous birds (Francour \& Thibault, 1996). They can directly catch fish through the water surface on the fly. Therefore, needlefish are frequently reported as a key prey for ospreys such as in the Canary Archipelago, at Santa Luzia in Cape Verde, and on Abker Island in the Farasan Archipelago (Fisher, 2001: fig. 3; Martins et al., 2011; Siviero et al., 2011) (see also Table 3). That seems to be also the case on Marawah Island where a great number of needlefish remains are reported. Note that queenfish also constitute a large part of catches on Salubah Island in the Farasan Archipelago (Fisher, 2001: fig. 3). On the other hand, most of the other main taxa that we identified are necto-benthic fish (i.e. swimming close to the bottom) such as tripodfish, groupers, flatheads, emperors, and seabreams. Kalvans and Bajinskis (2016) report that, in Latvia, ospreys essentially catch fish with a benthic lifestyle, such as carp (Cyprinus carpio, Carassius gibelio) and tench (Tinca tinca). They could be easily caught in fish ponds where the water is shallow. Furthermore, Swenson (1979) has also outlined that fish feeding, or living close to the bottom are generally slow moving and unwary. Since ospreys are able to dive up to a metre deep, benthic fish could constitute key targets if they occur in shallow waters (Prevost, 1982: 134). Therefore, the occurrence of significant proportions of tripodfish and emperors in the Marawah assemblages is consistent with the fact that the sea is quite shallow around the island. Mojarras and rabbitfish could be found in the mangroves and seagrass beds which predominate in the local area, while groupers and angelfish were probably caught close to the fringing reefs located about $2 \mathrm{~km}$ off the northern coast.

Diet specificities are observed depending on the geographic location of the perches. Tripodfish are more abundant in assemblages collected close to mangrove forests (south-west and north-east of the island) while emperor remains are principally found in assemblages located along sandy shores, in particular along the northern coast of the island (Figure 2.A). Conversely, needlefish are quite common in all the assemblages. Such distribution is convenient with the distinct habitat preferences of these species. 
At Marawah, size ranges are notably higher (46 cm in length for $462 \mathrm{~g}$ ) than it is commonly reported in other studies (about $28 \mathrm{~cm}, 300 \mathrm{~g}$ ). Because size estimations were not conducted on tripodfish remains, the results presented here tend to over-estimate the importance of emperors and needlefish sizes in the dataset. Hence, it is more than likely that size estimations should globally fit with those obtained in other study areas. Small fish are almost absent while bigger ones are typically over-represented in osprey diet according to Prevost (1982: 137). In fact, the latter author found that catch success increased with the fish size (Ibid: 122). The largest fish recorded at Marawah is a spangled emperor estimated to be about $1.85 \mathrm{~kg}$. Such large size is rarely reported while specimens generally reach up to 1-1.2 kg in other studies. However, in Scotland, ospreys often catch brown trouts (Salmo trutta) up to $2 \mathrm{~kg}$ (Carss \& Brockie, 1984: tab. 6). Interestingly, the needlefish caught by ospreys are bigger at Marawah than in other areas study, such as in Senegal where specimens ranged between 150 and 400 $\mathrm{g}$ (Table 3). According to Fisher (2001: 122), most of the smallest fish $(<10 \mathrm{~cm})$ could be interpreted as fish stomach contents since they are generally too small to have been caught by ospreys. Hence, they are generally found complete and do not show any talon or beak marks (Ibid).

\begin{tabular}{|c|c|c|c|c|c|c|c|}
\hline Location & Type & Reference & $\begin{array}{l}\text { Size range } \\
\quad(\mathrm{mm})\end{array}$ & $\begin{array}{l}\text { Weight } \\
\text { range }(\mathrm{g})\end{array}$ & $\mathrm{N}_{\operatorname{taxa}}$ & NISP & Main catches \\
\hline $\begin{array}{l}\text { SW Russia (Pra } \\
\text { River) }\end{array}$ & Inland & $\begin{array}{l}\text { Galushin, } \\
1958\end{array}$ & $80-400$ & $25-1000$ & 9 & 26 & $\begin{array}{l}\text { Leuciscus idus (30\%); Rutilus } \\
\text { rutilus (15\%); Abramis brama } \\
(12 \%)\end{array}$ \\
\hline SW Finland & Coastal & $\begin{array}{l}\text { Häkkinen, } \\
1978\end{array}$ & $100-570$ & $<1300$ & 10 & 198 & $\begin{array}{l}\text { Abramis brama }(39.6 \%) ; \\
\text { Scardinius erythrophthalmus } \\
\text { (22.7\%); Rutilus rutilus (14.6\%) }\end{array}$ \\
\hline $\begin{array}{l}\text { Scotland (Tayside } \\
\text { \& Grampian) }\end{array}$ & Inland & $\begin{array}{l}\text { Carss \& } \\
\text { Brockie, } 1994\end{array}$ & $180-600$ & $79-2032$ & 6 & 113 & $\begin{array}{l}\text { Oncorhynchus mykiss (37\%); } \\
\text { Rutilus rutilus (21\%); Perca } \\
\text { fluviatilis (18\%) }\end{array}$ \\
\hline Latvia & Inland & $\begin{array}{l}\text { Kalvans \& } \\
\text { Bajinskis, } \\
2016\end{array}$ & $160-480$ & $60-1080$ & 15 & 1501 & $\begin{array}{l}\text { Cyprinus carpio (47.2\%); Tinca } \\
\text { tinca (14.3\%); Carassius gibelio } \\
(11.3 \%)\end{array}$ \\
\hline NE Germany & Inland & $\begin{array}{l}\text { Müller et al., } \\
2005\end{array}$ & - & $<700$ & 6 & 562 & $\begin{array}{l}\text { Abramis brama (64.9\%); Tinca } \\
\text { tinca }(20.5 \%) \text {; Cyprinus carpio } \\
(4.8 \%)\end{array}$ \\
\hline $\begin{array}{l}\text { SE France (Corsica } \\
\text { Island) }\end{array}$ & Coastal & $\begin{array}{l}\text { Francour \& } \\
\text { Thibault, } \\
1996\end{array}$ & $\begin{array}{l}225-410 \\
\text { (mullets) }\end{array}$ & $\begin{array}{l}100-610 \\
\text { (mullets) }\end{array}$ & 12 & 741 & $\begin{array}{l}\text { Mugilidae (53.7\%); Sparidae : } \\
\text { Diplodus spp. \& Sarpa salpa } \\
(28.3 \%)\end{array}$ \\
\hline $\begin{array}{l}\text { NE USA (Virginia \& } \\
\text { Maryland) }\end{array}$ & Coastal & $\begin{array}{l}\text { Glass \& } \\
\text { Watts, } 2009\end{array}$ & $127-420$ & $18-850$ & 13 & 219 & $\begin{array}{l}\text { Cynoscion nebulosus (28.7\%); } \\
\text { Brevoortia tyrannus (24.2\%); } \\
\text { Migropogonias undulatus } \\
(12.3 \%)\end{array}$ \\
\hline $\begin{array}{l}\text { Canarian } \\
\text { Archipelago }\end{array}$ & Coastal & $\begin{array}{l}\text { Siverio et al., } \\
2011\end{array}$ & $\begin{array}{c}210-320 \\
\text { (carps) }\end{array}$ & $\begin{array}{c}140-320 \\
\text { (carps) }\end{array}$ & 15 & 307 & $\begin{array}{l}\text { Cheilopogon heterurus (42.7\%); } \\
\text { Tylosurus acus (36.6\%); Cyprinus } \\
\text { carpio (3.8\%) }\end{array}$ \\
\hline Cape Verde & Coastal & $\begin{array}{l}\text { Martins et } \\
\text { al., } 2011\end{array}$ & 207-622 & $49-1117$ & 35 & 1264 & $\begin{array}{l}\text { Trachinotus ovatus }(26.8 \%) ; \\
\text { Exocoetus volitans }(16.6 \%) ; \\
\text { Aulostomus strigosus }(14.6 \%)\end{array}$ \\
\hline
\end{tabular}




\begin{tabular}{|c|c|c|c|c|c|c|c|}
\hline Senegal & Coastal & Prevost, 1982 & $127-411$ & $42-1017$ & 54 & 2522 & $\begin{array}{l}\text { Mugilidae }(44.6 \%) \text {; Ethmalosa } \\
\text { fimbriata }(28.6 \%) \text {; Cheilopogon } \\
\text { heterurus }(7.8 \%)\end{array}$ \\
\hline $\begin{array}{l}\text { Tiran Island, North } \\
\text { Red Sea (Egypt) }\end{array}$ & Coastal & $\begin{array}{l}\text { Safriel et al., } \\
1985\end{array}$ & $76-1066$ & $<936$ & 52 & 982 & $\begin{array}{l}\text { Fistularia commersonii ( } 28 \%) ; \\
\text { Acanthurus nigrofuscus; Siganus } \\
\text { argenteus }\end{array}$ \\
\hline $\begin{array}{l}\text { Farasan Islands, } \\
\text { South Red Sea } \\
\text { (Saudi Arabia) }\end{array}$ & Coastal & Fisher, 2001 & $50-750$ & $33-1200$ & 56 & 688 & $\begin{array}{l}\text { Carangidae (23\%); Scaridae } \\
(19 \%) ; \text { Belonidae (11\%); } \\
\text { Siganidae (8\%) }\end{array}$ \\
\hline $\begin{array}{l}\text { Marawah Island } \\
\text { (UAE) }\end{array}$ & Coastal & Present study & $150-800$ & $80-1850$ & 12 & 1559 & $\begin{array}{l}\text { Triacanthidae }(46.8 \%) \text {; } \\
\text { Lethrinidae (28.1\%); Belonidae } \\
(11.9 \%)\end{array}$ \\
\hline
\end{tabular}

Table 3. Compared data on osprey diet from several studies.

\section{Discarding behaviors}

The proportion of preopercles is suprisingly important in the studied assemblage. Clancy (2005: 93) has observed that, in New South Wales (Australia), ospreys usually remove spines and opercle bones from fish before eating them. In the case of mullets, all parts other than opercle bones are swollen and digested. In this sense, Francour and Thibault (1996: tab. 1) found that mullet opercles and preopercles constitute almost $80 \%$ of the collected remains in Corsica (South-East France). Similarly, opercle bones are also among the dominant remains found in Finland, Latvia, and the Canarian Archipelago (Häkkinen, 1978; Siverio et al., 2011; Kalvans \& Bajinskis, 2016). Prevost (1982: 87) indicates that opercles of even the smallest fish caught were removed in Senegal. In this sense, we recorded opercles belonging to small mojarras in the present study.

It suggests that, at Marawah, ospreys could have removed the strong and spiny angelfish preopercles before eating the whole fish (Figure $7 n^{\circ} 5-6$ ). Indeed, no other remains belonging to angelfish were found. Fisher (2001: fig. 3) has also reported that Arabian angelfish (Pomacanthus asfur) constitute an important part of the osprey diet on Shura Island and Sadiq Island (Farasan Archipelago, Saudi Arabia). However, nothing is said about a preferential discarding of preopercles in his study. In Senegal, Prevost (1982: 97) pointed out that ospreys also remove beaks (premaxillae and dentaries), heads, and tails from needlefish, which is also consistent with observations made in the bone assemblages collected at Marawah (Figure 6 $\left.\mathrm{n}^{\circ} 1-4\right)$. It is more than likely that only the strongest and sharpest bones are discarded by ospreys.

Because of important taphonomic bias caused by the weathering and possible scavenging activities, the study of distinctive traces left by ospreys on fish remains is difficult. Nevertheless, we found that premaxillae and dentaries are generally found broken near the mid-length in the cranio-caudal axis. On another note, emperors' maxillary heads were frequently broken at level of their external processes (Figure $8 n^{\circ} 2-10$ ). This could be linked with the way of discarding bones adopted by ospreys. Before eating a fish, ospreys systematically remove the jaw bones - in particular if the teech are large or sharp. Hence, it is 
highly likely that when pulling on a premaxilla with its beak, the osprey exert strong pressure on the joint with the maxilla resulting in such particular break.

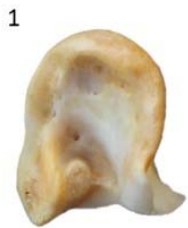

2

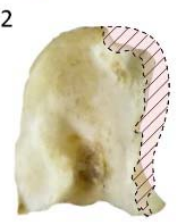

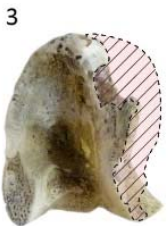

4

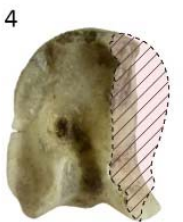

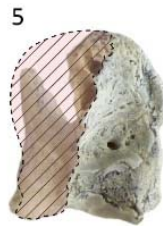

6

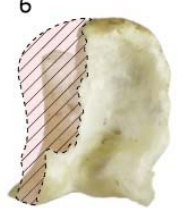

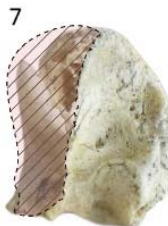

8

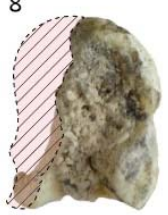

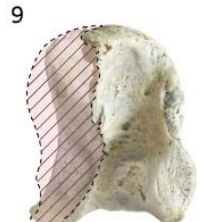

10

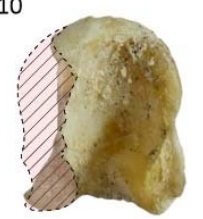

Figure 8. Sample of spangled emperor maxillae (cranial view) showing specific breakage of external processes (C K. Lidour). 1. Reference left maxilla of spangled emperor, Lethrinus nebulosus (MNHN ICOS 1333); 2-4. Left maxillae of spangled emperor, Lethrinus nebulosus; 5-10. Right maxillae of spangled emperor, Lethrinus nebulosus. Scale: $5 \mathrm{~mm}$

\section{Comparison with archaeological assemblages}

MR6.1 and MR6.3 are both archaeological sites dating from the Early Islamic period $\left(7-10^{\text {th }}\right.$ centuries AD) located in the western part of Marawah Island. A number of birds and small rodents remains have been observed alongside fish bones within several layers during the excavations conducted at these two sites (Beech, 2004: 125-128). The context of faunal accumulations remain hard to define in the absence of precise analyses of the domestic activities associated. It is why, in a previous paper (Beech, 2003), it was suggested that certain abandoned stone structures such as ancient kilns and tombs could have been used as perching points for ospreys on Marawah Island. Actually, an osprey has build its nest on the top of the pile of stones originating from the MR6 excavations.

\begin{tabular}{|c|c|c|c|c|c|}
\hline & \multicolumn{2}{|c|}{ MR6.1 } & \multicolumn{2}{|c|}{ MR6.3 } & MR11.C \\
\hline Period & \multicolumn{2}{|c|}{ Early Islamic } & \multicolumn{2}{|c|}{ Early Islamic } & Neolithic \\
\hline Type of site & \multicolumn{2}{|c|}{ Kilns } & \multicolumn{2}{|c|}{ Tombs } & Houses \\
\hline $\mathrm{N}$ & \multicolumn{2}{|c|}{937} & \multicolumn{2}{|c|}{723} & $>1000$ \\
\hline NISP & \multicolumn{2}{|c|}{262} & \multicolumn{2}{|c|}{100} & - \\
\hline \multirow[t]{2}{*}{ Mean size (in $\mathrm{cm}$ ) } & \multicolumn{2}{|c|}{$20-30$} & \multicolumn{2}{|c|}{$30-40$} & $20-25$ \\
\hline & NISP & $\%$ & NISP & $\%$ & Abundance \\
\hline Carcharhinidae & - & - & - & - & $* * *$ \\
\hline Pristidae & - & - & - & - & $* *$ \\
\hline Myliobatiformes & 38 & $14.5 \%$ & - & - & $* *$ \\
\hline
\end{tabular}




$\begin{array}{lccccc}\text { Belonidae } & 7 & 2.7 \% & 20 & 20 \% & * \\ \text { Carangidae } & 27 & 10.3 \% & 18 & 18 \% & * \\ \text { Lethrinidae } & 85 & 32.4 \% & 31 & 31 \% & * * * \\ \text { Haemulidae } & 2 & 0.8 \% & - & - & * * * \\ \text { Scaridae } & 66 & 25.2 \% & 5 & 5 \% & - \\ \text { Sphyraenidae } & - & - & 10 & 10 \% & - \\ \text { Sparidae } & 35 & 13.4 \% & 11 & 11 \% & * * \\ & & & & & - \\ \text { Others } & 40 & 15.3 \% & 5 & 5 \% & \end{array}$

Table 4. Compared assemblages of fish remains from several archaeological sites of Marawah Island (data from: Beech 2004; present study). ${ }^{*}$ little present; ${ }^{* *}$ moderately present; ${ }^{* * *}$ highly abundant.

At MR6.1, the assemblage is essentially composed of emperors, parrotfish (Scaridae), stingrays (Myliobatiformes), and seabreams. At MR6.3, the main fish taxa recorded are emperors, needlefish, seabreams, and barracudas (Sphyraenidae) (Table 4). The occurence of emperors, needlefish, and seabreams in the MR6 assemblages is quite consistent with the osprey diet on Marawah Island as reported by the present study. In this sense, a few flatheads and small queenfish are also represented. However, the occurrence of fast swimming pelagic fish such as torpedo scads (Megalaspis cordyla) and scombrids (tunas and mackerels), as well as large golden trevallies (Gnathanodon speciosus), but also the total absence of tripodfish in the assemblages are inconsistent with this view. While some authors have reported that ospreys often catch small sharks (Prevost, 1982: tab. 3.4; Fisher, 2001: 118), it is assumed that they avoid harmful fish such as stingrays (Ibid: 122). The presence of stingray vertebrae at MR6.1 thus cannot be related to the osprey diet. The anatomical items represented are quite diversified and do not show any evidence of a preferential discarding pattern. Vertebrae tend to be over-represented and opercle bones are only little recorded $(4.6 \%$ of the remains at MR6.1 and 1.4\% at MR6.3). No particular type of breakage similar to those previously observed on emperor maxillae (Figure 8 ) has been noted on the archaeological material. Fish are essentially represented by individuals about $20-30 \mathrm{~cm}$ long at MR6.1 and about $30-40 \mathrm{~cm}$ at MR6.3. The mean sizes thus globally fit with those of fish caught by ospreys as reported from several studies. Larger specimens are however under-represented in comparison with osprey accumulations.

Preliminary analyses of the material retrieved from MR11 Area C (Neolithic-6 ${ }^{\text {th }}$ millennium $\mathrm{BC}$ ) indicate that almost only small fish are present in the contexts where a number of bird remains have been observed. Recorded fish taxa are mainly seabream, grunts (Haemulidae), emperors, small requiem-sharks (Carcharhinidae), sawfish (Pristidae), stingrays, and carpet sharks (Chiloscyllium sp.). Seabream, grunts, and emperors are comprised between $20-25 \mathrm{~cm}$ in length (100-400 g) and the cartilaginous fish vertebrae do not exceed $1 \mathrm{~cm}$ in diameter. A few bigger specimens (up to 3-4 kg) consist of talang queenfish (Scomberoides commersonnianus), trevallies (Caranx sp., Gnathanodon speciosus), and groupers. Needlefish are only present in small numbers and other distinctive fish of osprey diet on Marawah Island such as tripodfish and angelfish are totally absent. Likewise, halfbeaks, mojarras, and 
rabbitfish are not represented at MR11 Area C. The assemblage is highly fragmented and essentially composed of vertebrae and otoliths. Even the smallest otoliths (mostly from small grunts) are in very good shape, suggesting that they were not affected by gastric fluids, such as examples from osprey nests. Apart a few premaxillae and dentaries, other parts of the skull are not represented. It is thus strongly consistent with the previous results obtained at the neighboring site of MR11 Area A (Lidour \& Beech, 2019).

Most of the characteristics of the Marawah archaeological assemblages are clearly inconsistent with the osprey diet in terms of taxonomic spectrum, size estimations, and anatomical representation. Therefore, it is possible to conclude that ospreys are not the primary agents responsible for fish remain deposits at these sites. While the study of the bird remains retrieved from MR11 Area $C$ is currently underway, the total absence of cut and fire marks on the bones suggest that birds were not consumed by the ancient inhabitants of the site. On another note, it is quite unlikely that effective bird-eating raptors (e.g. sea eagles, hawks or owls) could be responsible since beak and talon marks are not observed. One can thus expect fish remains associated to anthropic activities were mixed with post-occupational deposits possibly due to the presence of non-ichthyophagous birds nesting in the stone structures. The uppermost archaeological layers containing fish bones could have been contaminated with more recent bird remains after the collapse of the stone walls and the roof after the site has been abandoned.

\section{Conclusion}

The taxonomic spectrum of fish consumed by ospreys is directly dependent on the locally available species. On Marawah Island, it is generally composed of tripodfish, emperors, and needlefish. Other potential prey include a few blue crabs, locusts, and possibly cormorant. More generally, osprey diet focuses on slow-swimming fish occurring close to the surface and in shallow waters (Table 3). Catches are mainly comprised between 200 and $400 \mathrm{~g}$ in the majority of the diet studies available to date. Observations conducted on the discarded remains have also highlighted obvious taphonomic signatures of osprey predation. Hence, fish bone assemblages originating from osprey predation could be separated from archaeological accumulations according to the following characteristics:

- a spectrum with low diversity in terms of targeted species and size ranges;

- a preference for fish swimming just beneath the surface and slow benthic species occurring in shallow waters;

- presence of key prey species with low or no fishery value such as needlefish, tripodfish, and angelfish;

- under-representation of small fish while bigger ones are quite common and some can reach up to $2 \mathrm{~kg}$;

- a high proportion of bones belonging to the opercle series (i.e. opercles, preopercles); 
- a little proportion of vertebrae in comparison to remains belonging to the skull;

- presence of specific breaks on jaw bones, in particular on maxillae.

Therefore, based on the ecological data provided by the present study, the characteristics of the fish bone assemblages retrieved from MR6 and MR11 Area C are not consistent with those expected for osprey predation. It is thus quite sure that ospreys are not accumulation agents for fish remains at these archaeological sites. Although it is highly likely that birds were nesting within the MR11 Area C stone structures after the site had been abandoned, further investigations are still required to understand the deposition processes of bird bones and eggshell fragments within the rubble contexts (in particular which bird species are represented). While the identification of bird remains is currently undertaken, preliminary results tend to validate the presence of very small birds (such as Passeriformes or Apodiformes) which could have nested in the stone structures (M. Mashour, pers. comm.).

The osprey cannot be considered as a significant competitor to traditional fisheries such as those practiced in the Marawah Marine Biosphere Reserve. Indeed, targeted species globally differ between human and osprey - halfbeaks, needlefish, flatheads, angelfish, and tripodfish are generally of little interest to local fishermen. Groupers, queenfish, mojarras, seabreams, and rabbitfish have a higher economic value but are scarcely exploited by ospreys. Conversely, the spangled emperor is a prized food fish for both osprey and humans in the UAE. Recent prohibitions on spangled emperor fishing during reproductive periods have been promulgated by authorities to protect the renewal of fish stocks. Hence, it is quite unlikely that the dietary requirements of ospreys are threatened by fishing activites in the UAE. The modern tradition in the UAE of erecting perching posts for ospreys and allowing them to nest in certain locations, shows the respect and tolerance people have for them (Poole, 2019: 34-35). The conservation of ospreys could be improved by acting locally to reduce pollution and damage done to aquatic ecosystems (in particular fish-rich grounds such as mangroves, seagrass beds, and fringing reefs) and by reducing the impact of coastal development which may prevent ospreys from nesting and disturb their broods.

Excavations will continue on Marawah Island, where several other Neolithic stone-built houses have been identified. The present study is thus essential in order to determine if humans are the only accumulation agents at these archaeological sites. Archaeologists working on sites located close to riverine, lacustrine, and coastal settings should seriously consider the potential impact of osprey predation on fish bone accumulations given the worldwide distribution of this ichthyophagous raptor. Le Gall (1999) has indicated that an osprey couple and its nestlings are able to consume up to $300 \mathrm{~kg}$ of fish in a half-year - which is actually significantly more than a human family ${ }^{2}$. The present study is thus of significant importance for differentiating natural and archaeological accumulations of fish remains.

Recent ecological studies have focussed on connectivity between ecosystems, particularly from marine to coastal and inland areas. Marine subsidies can be present over hundreds of kilometres inland: from beaches, in the form of macroalgae and marine animal carcasses (Barreiro et al., 2011), to headwaters where anadromous fish such as salmonids spawn before dying. It has been shown that salmon subsidies (eggs and fish

\footnotetext{
${ }^{2}$ Korea scored highest with $78.5 \mathrm{~kg}$ per head in a year, followed by Norway with $66.6 \mathrm{~kg}$ (Guillen et al., 2019)
} 
carcasses) annually affect the stream-riparian food web, in particular by fertilizing the vegetation and feeding arthropod larvae (Collins \& Baxter, 2014). Mollusc shells also contribute to terrestrial ecosystems by improving the soil chemistry (by calcium and phosphorus intakes), drainage, and stability (Cox et al., 2020). Shell remains in archaeological shell middens can also assist the preservation of human and terrestrial faunal osteological remains by increasing the alkaline $\mathrm{pH}$ thereby aiding their preservation. In Eastern Arabia, anthropogenic shell-middens typically prevent the deflation of sand dunes and may host numerous animal burrows (from foxes, rodents, and lizards). However, the impact of shellmidden formation on coastal ecosystems has so far received little interest from researchers working in Arabia. Likewise, much work remains to be done more broadly regarding the impact of humans on the transport of ecological subsidies across ecosystems in the past. In particular, by studying how wildlife re-occupies and disturbs archaeological sites.

Ospreys participate fully in the transfer of aquatic subsidies into terrestrial landforms, by the deposition of discarded fish under their perches and by their nutrient-enriched droppings (Erlandson \& Moss, 2011). Further field research is required to investigate the possible impact of such deposits on terrestrial ecosystems on Marawah Island and elsewhere.

\section{Acknowledgments}

We would like to thank H. E. Mohammed Khalifa Al Mubarak (Chairman of the Department of Culture and Tourism), Rita Aoun-Abdo (Executive Director, Culture Sector), Jaber Al Merri (Director of the Historic Environment Department) and Peter Magee (Head of Archaeology and Palaeontology, Historic Environment Department) at DCT Abu Dhabi, for their support for our work on Marawah Island. Our thanks also to Mohammed Muftah Al Mansouri and Abdulla Ghanam bin Kadas Al Rumaithi who provided logistical support on the island. Special thanks go to Howell M. Roberts, Dominic A. Tomasi, Noura Hamad al-Hameli, and Myriam Al Dhaheri for their kind help for collecting the samples on Marawah Island. This study also made possible with the material and financial support of DCT Abu Dhabi and UMR 7209 AASPE. Special thanks to Dr. Philippe Béarez (MNHN) for his kind advice in preparing the present study. We would like to thank the anonymous reviewer for his thoughtful comments on our manuscript.

\section{References}

Aspinall, S., J., 1996. Status and Conservation of The Breeding Birds in the United Arab Emirates. Hobby Publications, Liverpool and Dubai.
Barreiro ,F., Gómez, M., Lastra, M., López, J., de la Huz, R., 2011. Annual cycle of wrack supply to sandy beaches: effect of the physical environment. Marine Ecology Progress Series 433, 65-74. doi: 10.3354/meps09130. 
Beech, M. J., 2003. The diet of Osprey Pandion haliaetus on Marawah island, Abu Dhabi emirate, UAE. Tribulus 13/1, 22-25.

Beech, M., J., 2004. In the Land of the Ichthyophagi modelling fish exploitation in the Arabian Gulf and Gulf of Oman from the 5th millennium $B C$ to the Late Islamic period. BAR 1217. British Archaeological Reports, Oxford

Beech, M., J., Cuttler, R., Moscrop, D., Kallweit, H., Martin, J., 2005. New evidence for the Neolithic settlement of Marawah Island, Abu Dhabi, United Arab Emirates. Proceedings of the Seminar for Arabian Studies 35, 37-56.

Beech M., J., Strutt K., Blue L., al-Kaabi A. K., Omar W. A., al-Haj el-Faki A. A., Lingareddy A. R., Martin J., 2016. 'Ubaidrelated sites of the southern Gulf revisited: the Abu Dhabi Coastal Heritage Initiative. Proceedings of the Seminar for Arabian Studies 46, 9-24.

Beech, M., J., Cuttler, R., T., H., Al Kaabi, A., K., El Faki, A., A., Martin, J., Al Hameli, N., H., Roberts, H., M., Spencer, P., Tomasi, D., Brunet, O., Crassard, R., 2019. Excavations at MR11 on Marawah Island (Abu Dhabi, UAE): new insight into the architecture and planning of Arabian Neolithic settlements and early evidence for pearling. Arabian Archaeology and Epigraphy. doi: https://doi.org/10.1111/aae.12148

Broughton, J., M., Cannon, V., I., Bogiatto, R., Arnold, S., Dalton, K., 2006. The taphonomy of owl-deposited fish remains and the origin of the Homestead Cave ichthyofauna. Journal of Taphonomy $4 / 2$, 69-75.
Carpenter, K., E., Krupp, F., Jones, D.A., Zajonz, U., 1997. The Living Marine Resources of Kuwait, Eastern Saudi Arabia, Bahrain, Qatar, and the United Arab Emirates. FAO Identification Field Guide for Fisheries Purposes. FAO, Rome.

Carss, D., N., Brockie, K., 1994. Prey remains at Osprey nests in Tayside and Grampian, 1987-1993. Scott. Birds, 17, 127-145.

Chaplin, R., 1971. The study of animal bones from archaeological sites. Seminar Press, New York.

Clancy, G., P., 2005. Feeding behaviour of the Osprey Pandion haliaetus on the North Coast of New South Wales. Corella 29/4, 91-96.

Collins, S., F., Baxter, C., V., 2014. Heterogeneity of riparian habitats mediates responses of terrestrial arthropods to a subsidy of Pacific salmon carcasses. Ecosphere 5, 1-14.

Cox, K., S., Davies, H., L., Davidson, K., H., Gerwing, T., G., Dudas, S., E., Juanes F., 2020. Shellfish subsidies along the Pacific coast of North America. Ecography 43, 114. doi: $10.1111 /$ ecog.04476

Dmokhovskiy, A., V., 1933. Birds of the Middle and Lower Pechora. Bulletin of the Moskow Naturalists Society 42/2. (in Russian)

Eagderi, S., Fricke, R., Esmaeili, H.R., Jalili, P., 2019. Annotated checklist of the fishes of the Persian Gulf: Diversity and conservation status. Iranian Journal of Ichthyology 6/1, 1-1171.

Egretaud, C., 1992. Etude de la biologie générale, et plus particulièrement du régime alimentaire de Lethrinus nebulosus 
du lagon d'Ouvéa (Nouvelle- Calédonie). ORSTOM, Nouméa.

Eriksson, M., O., G., 1986. Fish delivery, production of young, and nest density of Osprey (Pandion haliaetus) in southwest Sweden. Canadian Journal of Zoology 64/9, 1961-1965.

Erlandson, J., M., Moss, M., L., 2001. Shellfish feeders, carrion eaters and the archaeology of aquatic adaptations. American Antiquity 66, 413-432.

Erlandson, J., M., Rick, T.C., Collins, P., W., Guthrie, D., A., 2007. Archaeological implications of a bald eagle nesting site at Ferrelo Point, San Miguel Island, California. Journal of Archaeological Science 34/2, 255-271.

Evans, D., L., 1982. Status Reports on Twelve Raptors: Special Scientific Report Wildlife No. 238. United States Department of the Interior, Fish and Wildlife Service. Washington D.C.

Fisher, P., R., 2001. Ecology and behaviour of the Osprey Pandion haliaetus on the Farasan Islands, Red Sea, Saudi Arabia. PhD thesis. Manchester Metropolitan University.

Flemming, S., P., Smith, P.C., 1990. Environmental influences on Osprey foraging in Northeastern Nova Scotia. Journal of Raptor Research 24, 64-67.

Francour, P., Thibault, J.-C., 1996. The diet of breeding Osprey Pandion haliaetus on Corsica: exploitation of a coastal marine environment. Bird Study 43, 129-133.

Galarza, A., 2010. Fishing behaviour of the Osprey Pandion haliaetus in an estuary in the northern Iberian Peninsula during autumn migration. Revista Catalana d'Ornitologia 26, 56-60.

Galushin, V., M., 1958. On the ecology of the Osprey in the Okskiy reserve. Transactions of the Okskiy state nature reserve 2, 158-161. (in Russian)

Glass, K., W., Watts, B., W., 2009. Osprey diet composition and quality in high- and low salinity areas of lower Chesapeake Bay. Journal of Raptor Research 43, 27-36.

Golani, D., Bogorodsky, S.V., 2010. The fishes of the Red Sea - reappraisal and updated checklist. Zootaxa 2463, 1-135.

Golani, D., Orsi Relini, L., Massuti, E., Quignard, J.-P., 2002. CIESM Atlas of Exotic Species in the Mediterranean. Vol. 1. Fishes. CIESM Publishers, Monaco.

Guillaud, E., Lebreton, L., Béarez, P., 2018. Taphonomic signature of Eurasian eagle owl (Bubo bubo) on fish remains. Folia Zoologica 67/3-4, 143-153.

Guillaud, E., Morales-Muñiz, A., RosellóIzquierdo, E., Béarez, P., 2019. Taphonomy of Yellow-legged Gull (Larus michahellis) pellets from the Chafarinas islands (Spain). Canadian Journal of Zoology 97, 100-111.

Guillen, J., Natale, F., Carvalho, N., Casey, J., Hofherr, J., Druon, J.-N., Fiore, G., Gibin, M., Zanzi, A., Martinsohn, J., T., 2019. Global seafood consumption footprint. Ambio 48/2, 111-122.

Gusev, V., M., Chueva, G., I., 1951. Materials on the diet of some birds species in River llya area. Zoological Journal 30/6. (in Russian)

Grayson, D., 1984. Quantitative Zooarchaeology. Academic Press. 
Häkkinen, I., 1978. Diet of the Osprey Pandion haliaetus in Finland. Ornis Scandinavica (Scandinavian Journal of Ornithology) 9, 111-116.

Hutchins, J., B., 1984. Triacanthidae, in: Fischer, W., Bianchi, G. (Eds.), FAO species identification sheets for fishery purposes. Western Indian Ocean (Fishing Area 51). Vol. 4. FAO, Rome.

Ivanovski, V., V., 2012. Predator birds of the Belarus Lakeland: Monograph. Vitebsk State University Piotr M. Masherov. Ministry of Education, Republic of Belarus. (in Russian)

Kalvans, A., Bajinskis, J., 2016. The diet composition of breeding Ospreys (Pandion haliaetus) in Latvia. Environmental and Experimental Biology 14, 107-111.

Karjakin, I., V., 1998. Avian predators of the Ural Region. Falconiformes and Owls (Strigiformes). Perm: Center for Field Research Conservation Union Urals Animals. (in Russian)

Karna, S., K., Suresh, V., R., Mukerjee, M., Manna, R., K., 2018. Length-weight and Length-length relations of four fish species from the Chilika Lake, East coast of India. Applied Ichthyology 34/1, 224-226.

Khan, S., Javed, S. Junid, N., 2007. Survey of breeding Osprey Pandion haliaetus in Abu Dhabi Emirate. Tribulus 17, 77-79.

Khan, S., B., Javed, S., Shah, J., N., 2015. Ospreys in the Abu Dhabi Emirate; current breeding status and role of platforms as an aid to nesting. The Newsletter of the Middle East Falcon Research Group 32, 1416.
King, G., 1998. Abu Dhabi Islands archaeological survey. Trident Press, London.

Laboute, P., Grandperrin, R., 2006. Guide des poissons de Nouvelle-Calédonie Nouvelle édition. Editions Catherine Ledru, Nouméa.

Le Gall, O., 1999. Ichtophagie et pêches préhistoriques. Quelques données de l'Europe occidentale. State thesis. University of Bordeaux I.

Lloveras, L., Thomas, R., Lourenço, R., Caro, J., Dias, A., 2014. Understanding the taphonomic signature of Bonelli's Eagle (Aquila fasciata). Journal of Archaeological Science 49, 455-471.

Lidour, K., Vorenger, J., Béarez, P., 2018. Size and weight estimations of the spangled emperor (Teleostei: Lethrinidae: Lethrinus nebulosus) from bones measurements elucidate fishing grounds exploited and ancient seasonality at Akab (United Arab Emirates). International Journal of Osteoarchaeology 28/6, 681694. doi: https://doi.org/10.1002/oa.2683

Lidour, K., Beech, M., J., 2019. At the dawn of Arabian fisheries. Fishing activities of the inhabitants of the Neolithic tripartite house of Marawah Island, Abu Dhabi Emirate (United Arab Emirates). Arabian Archaeology and Epigraphy. doi: https://doi.org/10.1111/aae.12134

Lidour, K., Béarez, P., Charpentier, V., Méry, S., 2019. The prehistoric fisheries of Akab Island (United Arab Emirates). New insights into coastal subsistence during Neolithic in eastern Arabia. Journal of Island and Coastal Archaeology. doi: https ://doi.org/10.1080/15564

894.2018 .1531330 
Lieske, E., Myers, R., 1994. Coral reef fishes: Indo-Pacific \& Caribbean. Collins Pocket Guide. Harper Collins New York.

Mackrill, T., 2019. RSPB spotlight Ospreys. Bloomsbury Wildlife, London.

Martins, S., Freitas, R., Palma, L., Beja, P., 2011. Diet of Breeding Ospreys in Cape Verde Archipelago, Northwestern Africa. Journal of Raptor Research 45/3, 244-251.

Marquiss, M., Robinson, L., Tindal, E., 2007. Marine foraging by Ospreys in southwest Scotland: implications for the species in western Europe. British Birds 100, 456465.

Müller, T., Langgemach, T., Sulzberg, K., Köhler, D., 2005. Artenschutzprogramm Adler. Ministerium für Ländliche Entwicklung, Umwelt und Verbraucherschutz des Landes Brandenburg (MLUV). Referat für Presse und Öffentlichkeitsareit, Postdam.

Parin, N., V., 1967. Review of the marine Belonids of the western Pacific and Indian Oceans. Transactions of the P.P. Shirshov Institute of Oceanology 84, 3-83. (in Russian)

Poole, A., F., 1989. Ospreys, A Natural and Unnatural History. Cambridge University Press, New York.

Poole, A.F., 2019. Ospreys - The revival of a global raptor. John Hopkins University Press, Baltimore.

Prevost, Y., A., 1982. The Wintering Ecology of Ospreys in Senegambia. PhD thesis. University of Edimburgh.

Price, A., 2002. Simultaneous hotspots and coldspots of marine biodiversity and implications for global conservation. Marine Ecology Progress Series 241, 23-27.

Randall, J., E., 1995. Coastal fishes of Oman. University of Hawaii Press, Honolulu.

Russ, H., 2010. The Eurasian eagle owl (Bubo bubo): a fish bone accumulator on Pleistocene cave sites? Journal of Taphonomy 8, 281-290.

Russ, H., Jones, A., K., G., 2011. Fish remains in cave deposits: how did they get there? Cave and Karst Science 38/3, 117120.

Safriel, U., N., Ben-Hur, Y., Ben-Turia, A., 1985. The diet of the Osprey on Tiran Island; management implications for the population on the Northern Red Sea Islands, in: Moors P. J., (Ed.), Conservation of Island Birds. ICBP Technical Publication No. 3, Cambridge, pp. 181-193.

Shallard, B. and Associates, 2003. Fish resources assessment survey project of Abu Dhabi and UAE waters. Environmental Research and Wildlife Development Agency.

Siverio, M., Rodriguez, B., Rodriguez, A., Siverio, F., 2011. Inter-insular variation of the diet of osprey Pandion haliaetus in the Canarian archipelago. Wildlife Biology 17, 240-247.

Smith, M., M., Heemstra, P., C., 1986. Smiths' Sea Fishes. Springer-Verlag.

Sommer, C., Schneider, W., Poutier, J-M., 1996. The living marine resources of Somalia. FAO species identification field guide for fishery purposes. FAO, Rome. 
Swenson, J. E., 1979. The relationship between prey species ecology and dive success in Ospreys. Auk 96, 408-412.

Tamaei, S., 1999. Operation manual of fish hatchery, aquarium and mangrove cultivation in UAE. Marine Resources Research Center-Ministry of Agriculture and Fisheries, UAE.

Thibault, J., C., Triay R., Beabrun, P., Boukhalfa, D., Dominici, J., M., Torre, A., 1996. Osprey (Pandion haliaetus) in the Mediterranean: characteristics of a resident population with a patchy distribution, in: Muntaner, L., Mayol, J., (Zds.), Biologia y Conservacion de las Rapaces Mediterraneas. Monografias $\mathrm{n}^{\circ} 4$. SOE, Madrid, pp. 135-144

Tyler, J., C., 1980. Osteology, Phylogeny, and Higher Classification of the Fishes of the Order Plectognathi (Tetraodontiformes). NOAA Technical Report NMFS Circular 434. U.S. Department of Commerce, National Oceanic and Atmospheric Administration, National Marine Fisheries Service.

Wheeler, A., Jones, A. K., G., 1989. Fishes. Cambridge University Press, Cambridge. 